TARNOWSKIE STUDIA TEOLOGICZNE 37 (2018) NR 1-2, S. 345-369

http://dx.doi.org/10.15633/tst.3266

ks. Józef Stala ${ }^{1}$

UNIWERSYTET PAPIESKI JANA PAWŁA II W KRAKOWIE

\title{
Szczególnie zasłużeni dla nauki i kultury. Doktorzy honoris causa Uniwersytetu Papieskiego Jana Pawła I I w Krakowie w latach 2015-2018
}

Doctor honoris causa (łac. „doktor dla zaszczytu”) to tytuł honorowy nadawany przez jednostki akademickie osobom szczególnie zasłużonym dla nauki i kultury. Nadanie tego tytułu jest szczególnym wyróżnieniem dla osoby, która go otrzymuje, podkreśla również rangę przyznającej go uczelni wyższej. Uhonorowania tytułem nie uzależnia się od posiadania formalnego wykształcenia, jednak najczęściej przyznaje się go osobom o wysokim statusie społecznym, naukowym, kulturowym. Przyznanie tego zaszczytnego tytułu określa także hierarchię wartości wyznaczaną przez daną uczelnię, dlatego warto przyjrzeć się, komu Uniwersytet Papieski Jana Pawła II w Krakowie nadał tytuł doctor honoris causa w ostatnich latach. W niniejszym artykule zostaną przedstawione sylwetki osób zasłużonych, procedury i przebieg uroczystości przyznania tego tytułu przez Uniwersytet Papieski Jana Pawła II w Krakowie w latach 2015-2018 w kolejności chronologicznej.

${ }^{1}$ Ks. prof. dr hab. Józef Stala - kapłan diecezji tarnowskiej, profesor nauk teologicznych (katechetyka), profesor zwyczajny UPJPII. Prorektor ds. potencjału naukowego i współpracy międzynarodowej UPJPII, kierownik katedry nauk pedagogiczno-katechetycznych na Wydziale Teologicznym Sekcja w Tarnowie (w wie (UPJPII). Wykładowca katechetyki i kierownik pedagogizacji w tymże wydziale. Redaktor naczelny międzynarodowego periodyku naukowego „The Person and the Challenges”. Ekspert (nauki teologiczne i nauki o rodzinie) Polskiej Komisji Akredytacyjnej (PKA). 


\section{Profesor Elie Wiesel - 30 czerwca 2015}

15 grudnia 2014 roku Senat Uniwersytetu Papieskiego Jana Pawła II w Krakowie na wniosek Wydziału Filozoficznego podjął uchwałę w sprawie nadania prof. Eliemu Wieselowi godności doktora honoris causa UPJPII w Krakowie. Profesor Elie Wiesel jest pisarzem i dziennikarzem, twórcą pojęcia Holocaust, laureatem Pokojowej Nagrody Nobla. Zgodnie z procedurami powyższa uchwała była poprzedzona uzyskaniem nihil obstat Kongregacji Edukacji Katolickiej, a także dwoma pozytywnymi recenzjami: ks. prof. dr. hab. Łukasza Kamykowskiego i prof. dr. hab. Andrzeja Zolla. Ksiądz prof. Łukasz Kamykowski napisał między innymi: „Trudno jest napisać recenzję oceniającą dorobek człowieka, który otrzymał już dziesiątki doktoratów honorowych, gdyż stał się - przez swoje słowo i działalność - symbolem... uważam, że uhonorowanie przez Uniwersytet Papieski Jana Pawła II w Krakowie Elie Wiesela doktoratem honoris causa jest w pełni uzasadnione jego zasługami dla promocji pamięci o Zagładzie i wyciągania moralnych wniosków oraz kształcenia w duchu poszanowania godności osoby ludzkiej i wolności oraz szczerego dialogu między narodami, kulturami i religiami”'. Natomiast prof. Andrzej Zoll podkreślił między innymi, że „Przedstawione w tej recenzji fakty przemawiają jednoznacznie za trafnością decyzji Senatu Uniwersytetu Papieskiego Jana Pawła II w Krakowie o przyznaniu profesorowi Elie Wieselowi tytułu doktora honoris causa. Jest to Osoba wybitna, walcząca w swoim życiu o ochronę wartości ważnych dla całej ludzkości. Jako recenzent czuję się zaszczycony powierzeniem tej funkcji w przewodzie o nadanie tytułu doktora honoris causa"3. Na laudatora został wyznaczony biskup prof. dr hab. Tadeusz Pieronek.

Warto zastanowić się, dlaczego przyznano prof. Eliemu Wieselowi godność doktora honoris causa. Szukając odpowiedzi na to pytanie, można wymienić następujące wskazania: niezłomne zaangażowanie w walkę o obronę godności

2 Ł. Kamykowski, Recenzja dorobku profesora Eliego Wiesela w związku z przewodem o nadanie godności doktora honoris causa przez Wydział Filozoficzny Uniwersytetu Papieskiego Jana Pawła II w Krakowie, w: Promotio Doctoris Honoris Causa Pontificiae Universitatis Cracoviensis Ioannis Pauli II Reverendissimus Profesor Elie Wiesel, red. M. Wiertek, Kraków 2015, s. $14,36,38$.

A. Zoll, Opinia w sprawie nadania profesorowi Eliemu Wieselowi godności doktora honoris causa Uniwersytetu Papieskiego Jana Pawła II w Krakowie, w: Promotio Doctoris Honoris Causa Pontificiae Universitatis Cracoviensis Ioannis Pauli II Reverendissimus Profesor Elie Wiesel, red. M. Wiertek, Kraków 2015, s. 52. 
człowieka stanowiącej podstawę wolności oraz praw człowieka i obywatela; niestrudzone podejmowanie wysiłków zmierzających do głębszego zrozumienia przez społeczeństwa zbrodni Holokaustu oraz przybliżanie stanowiska żydowskiego w tej sprawie; wydobycie z zapomnienia i przywrócenie świadomości zbiorowej Polaków postaci Jana Karskiego - bohaterskiego emisariusza Polskiego Państwa Podziemnego; dowody poparcia dla Solidarności w trudnych dla polskiej demokracji latach 8o.; piętnowanie, poprzez programy edukacyjne skierowane ku młodzieży i inne działania fundacji „The Elie Wiesel Foundation for Humanity", zbrodni ludobójstwa, antysemityzmu, nietolerancji, obojętności i ksenofobii ${ }^{4}$.

Z powodu problemów zdrowotnych prof. Eliego Wiesela uroczystość nadania mu doktoratu honoris causa odbyła się 30 czerwca 2015 roku w Nowym Jorku w Park East Synagogue, którą nawiedził przed laty papież Benedykt XVI. Z Krakowa do Nowego Jorku przyjechała trzyosobowa delegacja: ks. prof. dr hab. Wojciech Zyzak, rektor UPJPII, ks. prof. dr hab. Józef Stala, prorektor UPJPII, bp prof. dr hab. Tadeusz Pieronek, laudator. Uroczystość rozpoczęło wykonanie hymnów narodowych Stanów Zjednoczonych i Izraela, których obywatelem jest prof. Elie Wiesel. Na początku spotkania rabin Arthur Schneier przypomniał swoje związki z Polską i Krakowem sięgające 1967 roku, w tym spotkania z prymasem Polski kard. Stefanem Wyszyńskim i ówczesnym arcybiskupem krakowskim Karolem Wojtyłą. Wracał pamięcią do spotkań z nim już jako papieżem Janem Pawłem II. Podkreślił ogromne znaczenie jego pontyfikatu dla zbliżania Kościoła do Żydów i judaizmu oraz traktowania ich jako rzeczywistych „starszych braci w wierze”. Następnie w imieniu „Towarzystwa Jana Karskiego” głos zabrał jego przewodniczący wykonawczy Waldemar Piasecki. Podkreślił symbolikę sytuacji i dwóch obecnych postaci: Tadeusza Pieronka i Elie Wiesela. Obaj w czasie wojny znaleźli się o kilkanaście kilometrów od siebie po dwóch stronach drutów KL Auschwitz. Jeden o piekle obozowym tylko słyszał, drugi doświadczał go. Obaj, w 2007 roku, otrzymali Nagrodę Orła Jana Karskiego. W nowojorskiej synagodze pierwszy był laudatorem, zaś drugi otrzymywał doktorat honorowy.

\footnotetext{
4 Por. Uchwała Nr 101/2014 Senatu Uniwersytetu Papieskiego Jana Pawła II w Krakowie $z$ dnia 15 grudnia 2014 roku $w$ sprawie nadania godności doktora honoris causa Uniwersytetu Papieskiego Jana Pawła II w Krakowie na wniosek Wydziału Filozoficznego prof. Eliemu Wieselowi, w: Promotio Doctoris Honoris Causa Pontificiae Universitatis Cracoviensis Ioannis Pauli II Reverendissimus Profesor Elie Wiesel, red. M. Wiertek, Kraków 2015, s. 10, 12.
} 
Rektor ks. prof. Wojciech Zyzak przedstawił proklamację o nadaniu prof. Eliemu Wieselowi doktoratu honoris causa oraz decydujące o tym motywy. Prezentował jego dzieło teologiczne i filozoficzne - definiowanie moralnego wymiaru i konsekwencji zbrodni Holocaustu, jego aktywność literacką i publicystyczną, zaangażowanie publiczne w obronę poniżanych i prześladowanych na całym świecie grup i mniejszości, łącznie z faktem, że to on wydobył z zapomnienia i przywrócił publicznej świadomości Jana Karskiego. Wszystkie powyższe motywy rozwinął w swej laudacji bp Tadeusz Pieronek, który przypomniał, iż prof. Elie Wiesel, który jest bezpośrednim świadkiem i symbolem potwornej zbrodni przeciwko ludzkości, jaką była eksterminacja narodu żydowskiego w niemieckich obozach koncentracyjnych podczas II wojny światowej i który podjął się trudnej misji utrwalenia w pamięci świata wiedzy o Holocauście. Stał się przez to „posłańcem do ludzkości”, z przesłaniem „pokoju, zadośćuczynienia i ludzkiej godności”, jak to określono w uzasadnieniu przyznanej mu w 1986 roku Pokojowej Nagrody Nobla. Przywołał jego książkę Noc - napisaną prostym językiem relację z życia w Auschwitz-Birkenau. Laudator przypominał także o publicznych wystąpieniach i działaniach prof. Eliego Wiesela na rzecz praw człowieka, mówiącego „nie” polityce apartheidu w Afryce Południowej, masakrom w Bośni, zbrodniom w Korei Północnej, prześladowaniom mniejszości nieislamskich w Sudanie i Kurdów w Turcji, łamaniu praw ludzkich przez reżim sowiecki. Laureat wspierał również polską „Solidarność” w najtrudniejszych czasach. Biskup Tadeusz Pieronek wiele miejsca poświęcił rozważaniu teologicznego problemu obecności Boga podczas II wojny światowej, które to zagadnienie podejmował Elie Wiesel'5 . Następnie prorektor ks. Józef Stala odczytał dyplom w języku łacińskim, po czym nastąpiło uroczyste wręczenie.

Mowa doktorska Profesora, prócz nawiązania do tradycji dialogu promowanego przez papieża Jana Pawła II, koncentrowała się na istocie bezwzględności i pozornej atrakcyjności zła. Jest ono obezwładniające, czyniąc z normalnych, uczciwych ludzi biernych i wygodnych świadków umywających ręce i odwracających oczy od zbrodni. Mimo koszmarnej lekcji II wojny z jej apogeum w postaci Holocaustu, dzisiejszy świat tej lekcji nie odrobił. Zło

5 Por. T. Pieronek, Laudacja z okazji nadania doktoratu honoris causa przez Wydziat Filozoficzny Uniwersytetu Papieskiego Jana Pawła II w Krakowie profesorowi Eliemu Wieselowi, w: Promotio Doctoris Honoris Causa Pontificiae Universitatis Cracoviensis Ioannis Pauli II Reverendissimus Profesor Elie Wiesel, red. M. Wiertek, Kraków 2015, s. 54-78. 
w wielu miejscach na świecie wciąż się rozwija, a ludzie decydujący o losach świata toczą debaty zamiast działać. „Nie możemy dać złu... drugiej szansy. Ono na to nie zasługuje!" - apelował Elie Wiesel. Na koniec delegacja UPJPII uhonorowała rabina Arthura Schneiera Złotym Medalem Jana Pawła II za Zasługi dla Archidiecezji Krakowskiej. Uroczystość nadania i wręczenia prof. Eliemu Wieselowi dyplomu doktora honoris causa UPJPII w Krakowie miała nie tylko ważny wymiar akademicki, ale także znaczenie historyczne dla relacji chrześcijańsko-żydowskich i polsko-żydowskich.

\section{Ojciec święty Benedykt XVI - 3 lipca 2015}

Rektor UPJPII ks. prof. dr hab. Wojciech Zyzak i rektor Akademii Muzycznej w Krakowie prof. dr hab. Zdzisław Łapiński skierowali do papieża Benedykta XV I list, prosząc o uczynienie zaszczytu przyjęcia tytułów doktora honorowego obydwu uczelni. List popierający starania uczelni napisał także ówczesny wielki kanclerz UPJPII kard. Stanisław Dziwisz. Na początku lutego 2015 roku papież emeryt odpowiedział, czyniąc w ten sposób wyjątek od zasady nieprzyjmowania żadnych wyróżnień odkąd wszedł w czas ukrycia: „Jednak propozycja przedstawiona mi przez Akademię Muzyczną w Krakowie i Uniwersytet Papieski Jana Pawła II w Krakowie to prawdziwy wyjątek. Jestem świadomy, że moje niewielkie teksty odnośnie do Muzyki Kościelnej nie zasługują na takie wyróżnienie. Jednak radość, że mogę w ten sposób na nowo stanąć blisko czcigodnej i umiłowanej osoby Świętego Jana Pawła II jest tak wielka, że nie mogę powiedzieć NIE w sprawie tego wyróżnienia. Przyjmuję zatem z wdzięcznością i radością doktorat honoris causa ze strony Waszych szanownych instytucji”"

Następnie na obydwu uczelniach rozpoczęły się wymagane procedury związane z nadaniem tytułu doktora honoris causa Benedyktowi XVI. 20 kwietnia 2015 roku Senat UPJPII w Krakowie podjął uchwałę w sprawie nadania Jego Świątobliwości Benedyktowi XVI godności doktora honoris causa Uniwersytetu Papieskiego Jana Pawła II w Krakowie. Zgodnie z procedurami, przed podjęciem powyższej uchwały stosowne recenzje przygotowali: ks. prof. AM dr hab. Jacek Bramowski, prof. dr hab. Teresa Malecka i ks. prof. dr hab. Andrzej Zając. Natomiast laudatorem został prof. dr hab. Stanisław Krawczyński. Ksiądz prof. Jacek Bramowski podkreślił w recenzji między innymi: „Teologia Benedykta XVI budzi we współczesnym człowieku tęsknotę za odnalezieniem

6 Archiwum Rektoratu Uniwersytetu Papieskiego Jana Pawła II w Krakowie. 
na nowo głębokiego sensu istnienia. Nie jest nim taka czy inna ideologia, ale osobowy Bóg, do którego podążać możemy również drogą piękna obecnego w muzyce. Konsekwentne ukazywanie tej nadziei dzisiejszemu światu w pełni uzasadnia decyzję o nadaniu godności doktora honoris causa Uniwersytetu Papieskiego Jana Pawła II w Krakowie Ojcu Świętemu Benedyktowi xvi. Prosząc Jego Świątobliwość o przyjęcie tej godności, wyrażamy pokorny hołd dla wielkości Jego myśli i czynów”. Natomiast prof. Teresa Malecka podkreśliła w recenzji między innymi: „Wspaniale się dzieje, że Uniwersytet Papieski Jana Pawła II i Akademia Muzyczna w Krakowie wystąpiły z inicjatywą uhonorowania najwyższą godnością akademicką wielkiego człowieka, głosiciela wartości najwyższych, podnosząc tym samym standardy kultury uniwersyteckiej, wzbogacając zarazem wartość etosu akademickiego. Wyrażenie zgody na przyjęcie tytułu doktora honoris causa przez Ojca św. Emeryta Josepha Ratzingera jest $\mathrm{z}$ kolei najwyższym zaszczytem dla naszych obu środowisk akademickich" ${ }^{\text {. }}$ Z kolei ks. prof. Andrzej Zając w recenzji między innymi przypomniał, że „Przyznanie doktoratu honoris causa Ojcu Świętemu Benedyktowi xvi przez dwie krakowskie uczelnie, które wspólnie prowadzą nauczanie muzyki w Międzyuczelnianym Instytucie Muzyki Kościelnej, ma wymowę symboliczną... uczelnie pragną w ten sposób wyrazić hołd i ogromną wdzięczność Ojcu Świętemu za jego głębokie, niezwykle cenne dla teologicznej refleksji nauczanie o muzyce, a także okazywanie przez wiele lat na wszystkich stanowiskach, jakie piastował, szczególnej troski o szlachetne piękno muzyki kościelnej i jej właściwe miejsce w sprawowaniu świętych obrzędów liturgicznych Chrystusowego Kościoła".

Godność doktora honoris causa została przyznana Jego Świątobliwości Benedyktowi xvi, emerytowanemu papieżowi w szczególności za: wielki

\footnotetext{
7 J. Bramowski, Recenzja w postępowaniu o przyjęcie godności doktora honoris causa Uniwersytetu Papieskiego Jana Pawła II w Krakowie przez Jego Świątobliwość Ojca Świętego Benedykta XVI, w: Promotio Doctoris Honoris Causa Pontificiae Universitatis Cracoviensis Ioannis Pauli II Sua Sanctitas Benedictus XVI, red. M. Wiertek, Kraków 2015, s. 144.

8 T. Malecka, Recenzja w postępowaniu o nadanie tytułu doktora honoris causa Uniwersytetu Papieskiego Jana Pawła II w Krakowie Ojcu Świętemu Benedyktowi XvI, w: Promotio Doctoris Honoris Causa Pontificiae Universitatis Cracoviensis Ioannis Pauli II Sua Sanctitas Benedictus XVI, red. M. Wiertek, Kraków 2015, s. 98.

9 A. Zając, Recenzja w postępowaniu o nadanie godności doktora honoris causa Jego Świqtobliwości Ojcu Świętemu Benedyktowi xvi przez Uniwersytet Papieski Jana Pawła II w Krakowie, w: Promotio Doctoris Honoris Causa Pontificiae Universitatis Cracoviensis Ioannis Pauli II Sua Sanctitas Benedictus XVI, red. M. Wiertek, Kraków 2015, s. 74.
} 
szacunek dla tradycji muzycznej Kościoła oraz niezwykłą wrażliwość na dialog muzyki z wiarą; okazywanie wyjątkowej troski o muzykę kościelną, zwłaszcza wykorzystywaną w liturgii; podkreślanie w swoim nauczania znaczenia via pulchritudinis, która może stać się drogą poznania i wielbienia Boga dla współczesnego człowieka; odważne dawanie swoim życiem, posługą, nauczaniem i pracą naukową świadectwa Prawdzie, która umacnia wiarę chrześcijańską w czasach duchowego zamętu spowodowanego przez liberalizm, postmodernizm i relatywizm oraz niestrudzone dążenie do przywrócenia Europie jej duchowego wymiaru; życzliwe wsparcie działań uczelni zmierzających do przekształcenia Papieskiej Akademii Teologicznej w Uniwersytet Papieski Jana Pawła II w Krakowie ${ }^{10}$.

Uroczystość miała miejsce w Castel Gandolfo 4 lipca 2015 roku. Kardynał Stanisław Dziwisz, metropolita krakowski i wielki kanclerz UPJPII, w swoim przemówieniu podkreślił: „Uniwersytet Papieski Jana Pawła II, erygowany przez Waszą Świątobliwość 19 czerwca 2009 roku, oraz Akademia Muzyczna w Krakowie postanowily dać wyraz naszej zbiorowej wdzięczności i przyznać Ojcu Świętemu doktorat honoris causa. Przyjęcie w drodze wyjątku tego wyróżnienia traktujemy jako wyraz szacunku Waszej Świątobliwości dla świętego Jana Pawła II. On sam - święty Papież - był zawsze pełen wdzięczności dla swojego najbliższego współpracownika - Prefekta Kongregacji Nauki Wiary. Jesteśmy pewni, że teraz spogląda na nas z wysoka i cieszy się z naszego spotkania”"

Następnie laudator, prof. Stanisław Krawczyński wygłosił laudację, w której między innymi powiedział: „Dziękujemy za to, że przyjmując tę godność, Wasza Świątobliwość staje się częścią naszej wspólnoty akademickiej, ubogacając ją w wymiarze teologicznym, muzycznym i ogólnoludzkim” ${ }^{12}$. Z kolei rektorzy UPJPII i AM przedstawili uchwały senatów oraz wręczyli ojcu świętemu Benedyktowi Xvi dyplomy doktora honoris causa obydwu uczelni.

${ }^{10}$ Por. Uchwała Nr 21/2015 Senatu Uniwersytetu Papieskiego Jana Pawła II w Krakowie $z$ dnia 20 kwietnia 2015 w sprawie nadania tytułu doktora honoris causa Uniwersytetu Papieskiego Jana Pawła II w Krakowie Jego Świętobliwości Ojcu Świętemu Benedyktowi xvI, w: Promotio Doctoris Honoris Causa Pontificiae Universitatis Cracoviensis Ioannis Pauli II Sua Sanctitas Benedictus XVI, red. M. Wiertek, Kraków 2015, s. 16.

${ }^{11}$ Archiwum Rektoratu Uniwersytetu Papieskiego Jana Pawła II w Krakowie.

${ }^{12}$ S. Krawczyński, Laudacja z okazji nadania godności doktoratu honoris causa Uniwersytetu Papieskiego Jana Pawła II w Krakowie i Akademii Muzycznej w Krakowie Jego Świątobliwości Benedyktowi XVI, w: Promotio Doctoris Honoris Causa Pontificiae Universitatis Cracoviensis Ioannis Pauli II Sua Sanctitas Benedictus XVI, red. M. Wiertek, Kraków 2015, s. 174. 
Natomiast papież emeryt Benedykt xvI, w swoim wykładzie doktorskim podkreślił: „W tej chwili mogę jedynie wyrazić moje najszczersze i najserdeczniejsze podziękowania za wielki zaszczyt, jaki mi zgotowaliście, przyznając doctoratus honoris causa. Dziękuję Wielkiemu Kanclerzowi, Jego Eminencji drogiemu Kardynałowi Stanisławowi Dziwiszowi i Władzom akademickim obu Uczelni. Cieszę się przede wszystkim, że w ten sposób jeszcze bardziej pogłębił się mój związek z Polską, z Krakowem, z ojczyzną naszego wielkiego Świętego Jana Pawła II. Bez niego bowiem trudno sobie nawet wyobrazić moją drogę duchową i teologiczną. Swoim żywym przykładem ukazał on nam również, jak mogą się ze sobą łączyć radość wielkiej muzyki sakralnej i zadanie wspólnego uczestnictwa w liturgii, podniosła radość i pokorna prostota celebracji wiary... W tym momencie warto może postawić pytanie podstawowe: Czym właściwie jest muzyka? Skąd pochodzi i do czego zmierza? Myślę, że można wskazać trzy «miejsca», z których wypływa muzyka. Pierwszym jej źródłem jest doświadczenie miłości. Kiedy ludzie byli zauroczeni miłością, otwierał się im inny wymiar istnienia, nowa wielkość i perspektywa rzeczywistości. Pobudzała ona także do wyrażania siebie w nowy sposób. Poezja, śpiew i w ogóle muzyka zrodziły się z tego doświadczenia wstrząsu, $\mathrm{z}$ tego otwierania się nowego wymiaru życia. Drugim źródłem muzyki jest doświadczenie smutku, dotknięcie śmiercią, bólem i otchłaniami istnienia. Także i w tym przypadku otwierają się w przeciwnym kierunku nowe wymiary rzeczywistości, które nie mogą znaleźć odpowiedzi w samych tylko słowach. Wreszcie trzecim miejscem pochodzenia muzyki jest spotkanie z tym, co Boże, od początku w jakiejś mierze definiującym to, co ludzkie. Tu najbardziej jest obecne coś zupełnie innego i coś zupełnie wielkiego, co pobudza w człowieku nowe sposoby wyrażania siebie. Może da się powiedzieć, że w istocie także w dwóch pozostałych obszarach - miłości i śmierci - dotyka nas tajemnica Boga, a więc w tym sensie dotknięcie przez Boga stanowi w sumie źródło muzyki. To wzruszające, gdy dostrzegamy, że na przykład w Psalmach ludziom nie wystarcza już sam tylko śpiew i znajdujemy odwołanie do wszystkich instrumentów: rozbudzona zostaje ukryta muzyka stworzenia, jej tajemniczy język. Wraz z Psałterzem, w którym mamy do czynienia z dwoma motywami miłości i śmierci, znajdujemy się wprost u źródeł muzyki Kościoła Bożego. Można powiedzieć, że jakość muzyki zależy od czystości i wspaniałości spotkania z tym, co Boże, z doświadczeniem miłości i cierpienia. Im bardziej czyste i prawdziwe jest to doświadczenie, tym czystsza i wspanialsza będzie także muzyka, która $\mathrm{z}$ niego się rodzi i rozwija... W tym miejscu chciałbym 
wyrazić myśl, która w ostatnim czasie pochłaniała mnie coraz bardziej, tym bardziej, im częściej różne kultury i religie wchodzą między sobą w relacje. W ramach najróżniejszych kultur i religii obecna jest wielka literatura, świetna architektura, malarstwo i wspaniałe rzeźby. I wszędzie jest także muzyka. A jednak w żadnym innym środowisku kulturalnym nie ma muzyki o wielkości dorównującej tej, która zrodziła się w kontekście wiary chrześcijańskiej: od Palestriny do Bacha, Haendla, aż po Mozarta, Beethovena i Brucknera. Muzyka zachodnia jest czymś wyjątkowym, niemającym sobie równych $\mathrm{w}$ innych kulturach. To powinno skłonić nas do zastanowienia... Działalność obydwu uczelni, które przyznają mi ten doktorat honoris causa, stanowi istotny przyczynek, aby wielki dar muzyki pochodzącej z tradycji wiary chrześcijańskiej pozostawał żywy i pomagał, by twórcza siła wiary także w przyszłości nie gasła. Za to wam wszystkim serdecznie dziękuję, nie tylko za zaszczyt, jakim mnie obdarzyliście, ale także za całą pracę, jaką wykonujecie w służbie pięknu wiary. Niech Pan was wszystkich błogosławi!"13

\section{Arcybiskup Celestino Migliore - 16 października 2015}

1 lipca 2015 roku Senat UPJPII w Krakowie na wniosek Wydziału Prawa Kanonicznego podjął uchwałę w sprawie nadania abp. Celestinowi Miglioremu, godności doktora honoris causa Uniwersytetu Papieskiego Jana Pawła II w Krakowie. Celestino Migliore, 25. doktor honoris causa U PJPII w Krakowie, to arcybiskup (od 2002) i dyplomata watykański, a w latach 2010-2016 nuncjusz apostolski w Polsce i dziekan Korpusu Dyplomatycznego w Rzeczypospolitej Polskiej.

Z zachowaniem obowiązujących procedur przedmiotowa uchwała została poprzedzona uzyskaniem nihil obstat Kongregacji Edukacji Katolickiej oraz dwoma pozytywnymi recenzjami: ks. prof. dr. hab. Tomasza Rozkruta (dziekana Wydziału Prawa Kanonicznego upjPII w Krakowie) i ks. prof. dr. hab. Henryka Stawniaka (dziekana Wydziału Prawa Kanonicznego uksw w Warszawie). Na laudatora został wyznaczony ks. prof. dr hab. Jan Maciej Dyduch (Wydział Prawa Kanonicznego U PJPII w Krakowie). Ksiądz prof. Tomasz Rozkrut napisał w recenzji między innymi: „W podsumowaniu należy zaznaczyć, że arcybiskupowi Celestinowi Miglioremu został już nadany doktorat honoris causa Uniwersytetu św. Jana w Nowym Jorku (26 stycznia 2006 r.) - był to dowód

\footnotetext{
${ }^{13}$ Archiwum Rektoratu Uniwersytetu Papieskiego Jana Pawła II w Krakowie.
} 
uznania ze strony środowiska amerykańskiego dla jego osoby oraz sposobu działania. Ponadto 19 stycznia 1999 roku został odznaczony Orderem Zasługi Republiki Włoskiej II Klasy. Natomiast w dniu pisania konkluzji do przedstawianej recenzji arcybiskup Celestino Migliore odbiera doktorat honorowy na Papieskim Wydziale Teologicznym we Wrocławiu. Powyższe uhonorowania niewątpliwie wynikają z rzetelnego wypełniania przez arcybiskupa Celestina Migliorego normy kanonu $363 \$ 1$ Kodeksu Prawa Kanonicznego, który stanowi: «Legatom Biskupa Rzymskiego zleca się funkcje reprezentowania go na sposób stały w Kościołach partykularnych lub także wobec państw i władz publicznych, do których są posyłani»" ${ }^{14}$. Natomiast drugi recenzent, ks. prof. Henryk Stawniak, podkreślił w recenzji między innymi, że „arcybiskup Celestino Migliore jest wybitną postacią światowej dyplomacji i prawdziwym autorytetem w tej dziedzinie. Jego niezwykła wiedza, czynne zaangażowanie w działalność Stolicy Apostolskiej i na rzecz Kościoła w Polsce wpisują go w poczet niezwykłych osobowości”'

Najwyższe akademickie wyróżnienie, godność doktora honoris causa, zostało przyznane abp. Celestinowi Miglioremu przede wszystkim za: kompetentne reprezentowanie biskupa rzymskiego oraz Stolicy Apostolskiej na forum międzynarodowym w poczuciu odpowiedzialności za dobro wspólne oraz godność każdego człowieka; ważne oraz znaczące wystąpienia na forum Organizacji Narodów Zjednoczonych, które ukazują jasny oraz czytelny głos Magisterium biskupa rzymskiego oraz Stolicy Apostolskiej w obronie najważniejszych wartości; chętny i czynny udział w różnych konferencjach oraz zjazdach naukowych; żywe i twórcze, a także mądre oraz odpowiedzialne współdziałanie na rzecz Kościoła katolickiego w Polsce, jego należnego funkcjonowania instytucjonalnego, wraz z promowaniem dokumentów papieskich w Kościele lokalnym; wyróżniające wypełnianie od pięciu lat zadań nuncjusza apostolskiego w Polsce, przez co Arcybiskup wpływa niewątpliwie znacząco, swoją gruntowną wiedzą oraz zdobytym doświadczeniem - jako wybitna

${ }^{14}$ T. Rozkrut, Recenzja w postępowaniu o nadanie godności doktora honoris causa Jego Ekscelencji arcybiskupowi Celestinowi Miglioremu, nuncjuszowi apostolskiemu w Polsce, w: Promotio Doctoris Honoris Causa Pontificiae Universitatis Cracoviensis Ioannis Pauli II Reverendissima Excellentia Caelestinus Migliore, red. M. Wiertek, Kraków 2015, s. 28.

${ }^{15}$ H. Stawniak, Recenzja w postępowaniu o nadanie godności doktora honoris causa Jego Ekscelencji arcybiskupowi Celestinowi Miglioremu, nuncjuszowi apostolskiemu $w$ Polsce, w: Promotio Doctoris Honoris Causa Pontificiae Universitatis Cracoviensis Ioannis Pauli II Reverendissima Excellentia Caelestinus Migliore, red. M. Wiertek, Kraków 2015, s. 46-47. 
postać dyplomacji watykańskiej - na kształtowanie współczesnych relacji państwo-Kościól, przede wszystkim w aspekcie dobra wspólnego ${ }^{16}$.

Uroczystość nadania abp. Celestinowi Miglioremu doktoratu honoris causa UPJPII w Krakowie odbyła się 16 października 2015 roku, w 37. rocznicę wyboru kard. Karola Wojtyły na stolicę Piotrową, i była połączona z inauguracją nowego roku akademickiego na UPJPII w Krakowie. Najpierw prorektor ks. prof. dr hab. Wojciech Misztal odczytał tekst uchwały Senatu UPJPII w sprawie nadania godności tytułu honoris causa. Następnie najważniejsze motywy nadania godności doktora honoris causa rozwinął w swej laudacji ks. prof. Jan M. Dyduch, który między innymi wskazał: „,arcybiskup Celestino Migliore jest znaczącą i wybitną osobistością w dyplomacji kościelnej, uznawaną w świecie. Jest nie tylko prominentnym dyplomatą, ale i dobrym pasterzem, prowadzącym lud Boży do Jezusa, do zbawienia, zgodnie z tradycyjną zasadą kanonistyczną salus animarum suprema lex esto"17. Następnie prorektor ks. prof. dr hab. Józef Stala odczytał w języku łacińskim dyplom doktora honoris causa, po czym rektor ks. prof. dr hab. Wojciech Zyzak wypowiedział formułę: „Reverendissimae Excellentiae nomen et dignitatem doctoris honoris causa, nomine Senatus Pontificiae Universitatis Cracoviensis Ioannis Pauli II conferimus" i uroczyście wręczył abp. Celestinowi Miglioremu dyplom doktora honoris causa UPJPII w Krakowie.

Kolejnym punktem uroczystości była mowa doktorska Arcybiskupa, która dotyczyła formatu społecznego jako przestrzeni życia w relacji z innymi i transcendencją. Podkreślił w niej: „Gdy papież Franciszek mówi o centralnym miejscu osób ubogich, w których odnajdujemy «ciało Chrystusa», nie uprawia łatwego pauperyzmu, ale interpretuje rzeczywistość ludzką w świetle Chrystusa, który uczynił ją swoją, czyniąc ludzi dziećmi Boga, a przez to braćmi i siostrami

${ }^{16}$ Por. Uchwała Nr 62/2015 Senatu Uniwersytetu Papieskiego Jana Pawła II w Krakowie $z$ dnia 1 lipca 2015 roku w sprawie nadania tytułu doktora honoris causa Uniwersytetu Papieskiego Jana Pawła II w Krakowie Jego Ekscelencji Księdzu Arcybiskupowi Celestinowi Miglioremu - Nuncjuszowi Apostolskiemu w Polsce, w: Promotio Doctoris Honoris Causa Pontificiae Universitatis Cracoviensis Ioannis Pauli II Reverendissima Excellentia Caelestinus Migliore, red. M. Wiertek, Kraków 2015, s. 5-6.

${ }^{17}$ M. Dyduch, Laudacja $z$ okazji nadania tytułu doktora honoris causa przez Uniwersytet Papieski Jana Pawła II w Krakowie arcybiskupowi Celestinowi Miglioremu, nuncjuszowi apostolskiemu w Polsce, w: Promotio Doctoris Honoris Causa Pontificiae Universitatis Cracoviensis Ioannis Pauli II Reverendissima Excellentia Caelestinus Migliore, red. M. Wiertek, Kraków 2015, S. 58-59. 
między sobą. Ta wizja człowieka, widzianego w świetle Chrystusa, pokazała swoją wielką wartość krytyczną, a jednocześnie swój walor naprawczy i konstruktywny w stosunku do zawirowań antropologicznych dzisiejszej kultury, jak również odnośnie do przejawów niesprawiedliwości, konfliktów, przemocy i dyskryminacji. Jak mi się wydaje, w tej perspektywie także ośrodki akademickie, wychowawcze i formacyjne, o charakterze chrześcijańskim, katolickim, powinny wypracowywać nowe, kreatywne i programowe wizje świata, dając tym samym swój wkład w budowanie świata, w którym lepiej się żyje”18.

\section{Ksiądz profesor Michał Heller - 22 czerwca 2016}

18 kwietnia 2016 roku Senat UPJPII w Krakowie na wniosek Wydziału Filozoficznego podjął uchwałę w sprawie nadania ks. prof. dr. hab. Michałowi Hellerowi godności doktora honoris causa Uniwersytetu Papieskiego Jana Pawła II w Krakowie. Ksiądz prof. Michał Heller, 26. doktor honoris causa UPJPII w Krakowie, to kapłan diecezji tarnowskiej, profesor nauk filozoficznych specjalizujący się w filozofii przyrody, fizyce, kosmologii relatywistycznej oraz relacji nauka-wiara. Jest pracownikiem UPJPII oraz Watykańskiego Obserwatorium Astronomicznego, założycielem, fundatorem i dyrektorem Centrum Kopernika Badań Interdyscyplinarnych, członkiem Polskiej Akademii Nauk. W 2008 roku otrzymał prestiżową nagrodę Templetona, która jest przyznawana za pokonywanie barier między nauką a religią. To ósmy tytuł doktora honoris causa przyznany ks. prof. Michałowi Hellerowi, wcześniej nadały go: Akademia Górniczo-Hutnicza (1996), Uniwersytet Kardynała Stefana Wyszyńskiego w Warszawie (2009), Uniwersytet Przyrodniczy w Poznaniu (2010), Politechnika Warszawska (2012), Uniwersytet Jagielloński (2012), Uniwersytet Przyrodniczy w Lublinie (2014), Uniwersytet Śląski w Katowicach (2015), Uniwersytet Papieski Jana Pawła II w Krakowie (2016).

Zgodnie z obowiązującymi procedurami przedmiotowa uchwała została poprzedzona uzyskaniem nihil obstat Kongregacji Edukacji Katolickiej oraz dwoma pozytywnymi recenzjami, które napisali: prof. Dominique Lambert (Uniwersytet w Namur) i prof. dr hab. Andrzej Staruszkiewicz (Uniwersytet

${ }^{18}$ C. Migliore, Lectio magistralis. Format społeczny jako przestrzeń życia $w$ relacji z innymi i transcendencja, w: Promotio Doctoris Honoris Causa Pontificiae Universitatis Cracoviensis Ioannis Pauli II Reverendissima Excellentia Caelestinus Migliore, red. M. Wiertek, Kraków 2015, s. 69 . 
Jagielloński w Krakowie). Na laudatora została wyznaczona prof. dr hab. Alicja Michalik (Uniwersytet Papieski Jana Pawła II w Krakowie). Profesor Dominique Lambert napisał w recenzji między innymi: „Biorąc pod uwagę relacje między naukami, filozofią i teologią, zdajemy sobie sprawę, że prof. Heller otworzył cały szereg dróg, które były całkowicie nieklasyczne, a obecnie ożywiają, dzięki jego inicjatywie, wiele działań badawczych..."19 Natomiast drugi recenzent, prof. Andrzej Staruszkiewicz, wskazał między innymi: „Amatorstwo, powierzchowność i ignorancja wspierająca arogancję to znaki rozpoznawcze oświeceniowego literata. Tymczasem teolog nauki według Księdza Profesora powinien zajmować się profesjonalnie określonym działem nauki. To od razu ustawia go w sytuacji, w której obszar wiedzy jest nieskończenie mały wobec obszaru niewiedzy, a to w naturalny sposób jest źródłem pokory... Destrukcja kulturalna, którą spowodowało oświecenie, a później marksizm miała jedno ze swoich źródeł w arogancji niedouczonych literatów. Ksiądz Profesor wskazuje bardzo dobre i moim zdaniem obiecujące lekarstwo w postaci teologa nauki, będącego dokładnym przeciwieństwem oświeceniowego literata" ${ }^{20}$.

Najwyższe akademickie wyróżnienie, godność doktora honoris causa, zostało przyznane ks. prof. Michałowi Hellerowi w szczególności za: wyznaczanie nowych kierunków badawczych w kosmologii relatywistycznej oraz kosmologii kwantowej, m.in. za prace o osobliwościach w modelach kosmologicznych, a także za prace nad zastosowaniem nowych, głębszych struktur matematycznych do kosmologii; wkład wniesiony w odnowę filozofii przyrody, filozofii nauki oraz historii nauki przez wprowadzenie wiele oryginalnych podejść o charakterze interdyscyplinarnym, co szczególnie widoczne jest w takich tematach, jak: filozofia w nauce, teologia nauki, matematyczność przyrody, człowiek i Wszechświat, racjonalność świata; skuteczne budowanie mostów między nauką a wiarą, których szczególnym wyrazem jest ciągłe wskazywanie na istotną potrzebę dialogu nauki i religii $\mathrm{w}$ rozwiązywaniu trudnych

19 D. Lambert, Recenzja dorobku naukowego ks. prof. Michała Hellera w związku z przyznaniem doktoratu honoris causa przez Uniwersytet Papieski Jana Pawła II w Krakowie, w: Promotio Doctoris Causa Pontificiae Uniwersitatis Cracoviensis Ioannis Pauli II Reverendissimus Profesor Michael Heller, red. M. Wiertek, Kraków 2016, s. 31-32.

${ }_{20}$ A. Staruszkiewicz, Recenzja dorobku ks. prof. Michała Hellera w związku $z$ wnioskiem Rady Wydziału Filozoficznego o nadanie mu tytułu doktora honoris causa Uniwersytetu Papieskiego Jana Pawła II w Krakowie, w: Promotio Doctoris Causa Pontificiae Universitatis Cracoviensis Ioannis Pauli II Reverendissimus Profesor Michael Heller, red. M. Wiertek, Kraków 2016, S. $41-42$. 
problemów z zakresu współoddziaływania nauki, filozofii i teologii; świadectwo wiary o wymiarze racjonalnym, w którym racjonalność potrafiła przełamywać uprzedzania i docierać do ludzi o różnych przekonaniach; zasługi dla Uniwersytetu Papieskiego Jana Pawła II na polu nauki, filozofii i teologii oraz rozsławianie swoją wiedzą i kompetencją Alma Mater w Polsce i na całym świecie, a także zyskiwanie grona uczniów i naśladowców; działalność organizacyjną oraz przykłady otwartości na taką współpracę, której owocem są liczne działające organizacje i towarzystwa naukowe.

Uroczystość nadania ks. prof. Michałowi Hellerowi doktoratu honoris causa UPJPII w Krakowie odbyła się 26 czerwca 2016 roku w Bibliotece UPJPII w Krakowie. Najpierw rektor ks. prof. dr hab. Wojciech Zyzak otworzył nadzwyczajne posiedzenie senatu oraz przywitał przybyłych gości. Następnie prorektor ks. prof. dr hab. Janusz Mastalski odczytał tekst uchwały nr 22/2016 Senatu UPJPII w Krakowie $\mathrm{z}$ dnia 18 kwietnia 2016 roku w sprawie nadania godności tytułu honoris causa ks. prof. Michałowi Hellerowi. Z kolei najważniejsze motywy nadania godności doktora honoris causa Księdzu Profesorowi rozwinęła w swej laudacji prof. Alicja Michalik, która między innymi wskazała: „Michał Heller jest światowej klasy uczonym i niezwykle skromnym człowiekiem. Należy On do znakomitych gremiów naukowych, współpracujących z wybitnymi uczonymi w różnych krajach. Jego wielki dorobek naukowy cieszy się dużym uznaniem w świecie nauki i filozofii. Znalazło to odzwierciedlenie w przyznaniu mu różnych nagród i odznaczeń. Do najważniejszych należą: oprócz Nagrody Templetona, Nagroda im. Hugona Steinhausa, Nagroda im. Józefa Tischnera i Nagroda im. Księdza Idziego Radziszewskiego, Super Wiktor Specjalny i Medal Św. Jerzego. Odznaczony został Krzyżem Komandorskim z Gwiazdą Orderu Odrodzenia Polski i Orderem Orła Białego. Czcigodny i Dostojny Doktorze honoris causa, kieruję wyrazy największego uznania dla osiągnięć i osoby Księdza Profesora. Życzę Księdzu Profesorowi dalszych wspaniałych sukcesów naukowych i dużo zdrowia"21.

Po przedstawieniu laudacji prorektor ks. prof. Józef Stala odczytał w języku łacińskim dyplom doktora honoris causa, po czym rektor ks. prof. Wojciech Zyzak wypowiedział właściwą formułę i wręczył ks. prof. Michałowi Hellerowi

${ }^{21}$ A. Michalik, Laudacja dla ks. prof. dr. hab. Michała Hellera $z$ okazji nadania mu godności doktora honoris causa przez Wydział Filozoficzny Uniwersytetu Papieskiego Jana Pawła II $w$ Krakowie, w: Promotio Doctoris Causa Pontificiae Universitatis Cracoviensis Ioannis Pauli II Reverendissimus Profesor Michael Heller, red. M. Wiertek, Kraków 2016, s. 51-52. 
dyplom doktora honoris causa UPJPII w Krakowie. Po nadaniu godności życzenia i gratulacje wypowiedzieli wielki kanclerz UPJPII ks. kard. Stanisław Dziwisz oraz sekretarz stanu w Ministerstwie Nauki i Szkolnictwa Wyższego prof. Aleksander Bobko. Później ks. prof. Józef Stala odczytał listy gratulacyjne.

Kolejnym punktem uroczystości była mowa doktorska Księdza Profesora, która była prowokująco zatytułowana: Teologia dzisiaj - detronizowanie królowej?. Doktor honoris causa między innymi podkreślił: „Jeżeli teologia ma zdobyć wiarygodność w oczach dzisiejszego wykształconego człowieka, to musi się mu przedstawić jako racjonalnie zorganizowane poznanie, czyli w tej warstwie, która łączy ją z naukami, powinna stosować te same metody, co one. Ale pod sankcją utraty swojej identyczności musi także zachować własną specyfikę. A jądrem tej specyfiki jest Wydarzenie. Poprzez Wydarzenie otwiera się ona na Coś, co wykracza poza wszelkie metody czysto ludzkiego poznania. Ale nie może to być furtką dla irracjonalności. Wkraczając w ludzką historię, Wydarzenie nieuchronnie weszło w kontakt z ludzką myślą. I to jest dla niej Wielką Szansą, bo uświadamia jej, że obszar dostępny ludzkiej racjonalności nie pokrywa się z całą rzeczywistością, albo - to samo nieco inaczej - że granice ludzkiej racjonalności nie pokrywają się z granicami racjonalności w ogóle. Wydarzenie mówi teologowi, że granice naukowej metody są tylko granicami człowieka"22.

\section{Kardynał profesor Gerhard Ludwig Müller - 16 października 2017}

15 maja 2017 roku UPJPII w Krakowie na wniosek Wydziału Teologicznego podjął uchwałę w sprawie nadania kard. Gerhardowi Ludwigowi Müllerowi godności doktora honoris causa Uniwersytetu Papieskiego Jana Pawła II w Krakowie. Kardynał Gerhard Ludwig Müller to 27. doktor honoris causa UPJPII w Krakowie. W 1990 roku został powołany na członka Komisji Wiary przy Konferencji Episkopatu Niemiec, a w 1998 roku papież Jan Paweł II powołał go na członka Międzynarodowej Komisji Teologicznej na cztery lata. W tym też czasie pełnił funkcję peritusa podczas watykańskiego Synodu o Europie (1999), Synodu o Biskupach (2001, 2005). 24 listopada 2002 roku

${ }^{22}$ M. Heller, Teologia dzisiaj - detronizowanie królowej?, w: Promotio Doctoris Causa Pontificiae Universitatis Cracoviensis Ioannis Pauli II Reverendissimus Profesor Michael Heller, red. M. Wiertek, Kraków 2016, s. 62. 
przyjął sakrę biskupią z rąk Josepha Ratzingera, prefekta Kongregacji Nauki Wiary, i jako 77. biskup Regensburga z wezwaniem „Dominus Iesus” objął biskupstwo w Regensburgu. Przez dziesięć pełnych lat pasterzował w diecezji ratyzbońskiej. 2 lipca 2012 roku papież Benedykt xvi powołał bp. Müllera na stanowisko prefekta Kongregacji Nauki Wiary, a 22 lutego 2014 roku papież Franciszek powołał go do kolegium kardynalskiego.

$\mathrm{Z}$ zachowaniem obowiązujących procedur przedmiotowa uchwała została poprzedzona uzyskaniem nihil obstat Kongregacji Edukacji Katolickiej oraz dwoma pozytywnymi recenzjami: ks. prof. dr. hab. Krzysztofa Góździa (profesor KUL) oraz ks. prof. dr. hab. Jana Daniela Szczurka (profesor UPJPII). Na laudatora został wyznaczony ks. prof. dr hab. Andrzej Napiórkowski osPPE (profesor UPJPII).

Ksiądz prof. Krzysztof Góźdź napisał w recenzji między innymi: „W rezultacie omówiona tu droga naukowa, działalność eklezjalna w Kościele lokalnym i powszechnym oraz działalność naukowa w ogóle - jednoznacznie wskazują, że postępowanie Senatu Uniwersytetu Papieskiego Jana Pawła II w Krakowie w sprawie nadania najwyższej godności akademickiej doktora honoris causa dla Jego Eminencji kardynała Gerharda Ludwiga Müllera - jest ze wszech miar słuszne. Ukazane przymioty osobowe i naukowe, kapłańskie i chrześcijańskie, dotyczące zarówno duszy, serca, jak i umysłu, wyrażają całkowite poświęcenie Kandydata totalnej służbie Kościołowi Chrystusowemu, a w tym także Urzędowi św. Piotra. Kardynał Gerhard Ludwig Müller jest świetlanym przykładem prawdziwego chrześcijanina, człowieka bez reszty oddanego Bogu i ludziom, kapłana i biskupa, profesora i wybitnego dogmatyka, który radośnie i prawdziwie służy w imię posłannictwa Chrystusowego, głosząc całym swoim życiem Jego Ewangelię. Zasługuje on więc w pełni na zaszczytne akademickie wyróżnienie"23. Natomiast drugi recenzent, ks. prof. Jan D. Szczurek, podkreślił $\mathrm{w}$ recenzji między innymi, że „Doktorat honoris causa jest najwyższym wyróżnieniem akademickim. W przypadku Kardynała Müllera Uniwersytet Papieski Jana Pawła II w Krakowie nie będzie pierwszym, który mu nadaje to wyróżnienie. Otrzymał je bowiem już od Katolickiego Uniwersytetu

${ }^{23}$ K. Góźdź, Opinia w postępowaniu o nadanie godności doktora honoris causa Uniwersytetu Papieskiego Jana Pawła II w Krakowie Jego Eminencji Gerhardowi Ludwigowi Müllerowi, prefektowi Kongregacji Nauki Wiary, w: Promotio Doctoris Honoris Causa Pontificiae Universitatis Cracoviensis Ioannis Pauli II Eminentissimus Professor Cardinalis Gerhard Ludwig Müller, red. M. Mastyło, Kraków 2017, s. 23-24. 
Lubelskiego (2004 r.), Uniwersytetu Kardynała Stefana Wyszyńskiego w Warszawie (2007 r.), Papieskiego Uniwersytetu w Limie (Perú, 2008 r.) i Papieskiego Wydziału Teologicznego we Wrocławiu (2015 r.). Zgodnie ze Statutem naszego Uniwersytetu doktorat honoris causa może być nadany «osobom szczególnie zasłużonym dla Kościoła po otrzymaniu zgody Senatu i Wielkiego Kanclerza oraz po uzyskaniu nihil obstat Stolicy Apostolskiej» (\$ 83). Przedstawione wyżej fakty z życia i działalności ks. Ludwiga Gerarda kardynała Müllera wskazują jednoznacznie, że fatycznie jest on osobą szczególnie zasłużoną nie tylko dla Kościoła w swojej ojczyźnie, ale także w Polsce, a przede wszystkim dla Kościoła powszechnego... Jako teolog i biskup niemiecki jest także zasłużony dla Kościoła w Polsce, przede wszystkim poprzez swoją życzliwość i szacunek dla jego działalności ewangelizacyjnej. Chętnie nas odwiedza, głosi słowo Boże i dzieli się swoimi przemyśleniami, z szacunkiem wspomina trudne doświadczenia naszego Narodu, szczególnie pod dominacją totalitaryzmu nazistowskiego i potem komunistycznego. Jest promotorem dobrych relacji nie tylko między Kościołem w Polsce i w Niemczech, ale także między naszymi narodami" ${ }^{24}$.

Najwyższe akademickie wyróżnienie, godność doktora honoris causa, zostało przyznane kard. Gerhardowi Ludwigowi Müllerowi w szczególności za: „godną naśladowania postawę prawdziwego chrześcijanina, człowieka oddanego Bogu i ludziom bez reszty, kapłana i biskupa, profesora i wybitnego dogmatyka, który radośnie i prawdziwie służy ludziom w imię posłannictwa Chrystusowego, głosząc całym swoim życiem Jego Ewangelię; wierne stanie na straży nauki Kościoła, poprzez wspieranie w wypełnianiu swych misji dwóch kolejnych papieży: Benedykta XVI i Franciszka; konsekwentne dbanie o to, by prawdy wiary zgłębiane drogą naukowego dociekania wiązać z codziennym życiem konkretnej osoby w Chrystusie, by te prawdy formułowane w sposób „teoretyczny” miały zastosowanie „praktyczne”; gorliwe zaangażowanie w dialog ekumeniczny i międzyreligijny przy jasnym zachowaniu integralności depozytu wiary; promowanie dobrych relacji nie tylko między Kościołem w Polsce i w Niemczech, ale także między narodem polskim i niemieckim

${ }^{24}$ J. D. Szczurek, Recenzja w postępowaniu o nadanie godności doktora honoris causa Jego Eminencji kardynałowi Gerhardowi Ludwigowi Müllerowi, prefektowi Kongregacji Nauki Wiary, w: Promotio Doctoris Honoris Causa Pontificiae Universitatis Cracoviensis Ioannis Pauli II Eminentissimus Professor Cardinalis Gerhard Ludwig Müller, red. M. Mastyło, Kraków 2017, s. 53-54, 55-56. 
poprzez obecność na najważniejszych uroczystościach kościelnych w ojczyźnie Świętego Jana Pawła II oraz udział w licznych sympozjach i konferencjach organizowanych na polskich uczelniach ${ }^{25}$.

Uroczystość nadania kard. Gerhardowi Ludwigowi Müllerowi doktoratu honoris causa Uniwersytetu Papieskiego Jana Pawła II w Krakowie odbyła się 16 października 2017 roku i była połączona $\mathrm{z}$ inauguracją nowego roku akademickiego. Najpierw rektor ks. prof. dr hab. Wojciech Zyzak odczytał w języku niemieckim tekst uchwały Senatu UPJPII w Krakowie w sprawie nadania godności tytułu honoris causa. Następnie najważniejsze motywy nadania godności doktora honoris causa rozwinął w swej laudacji ks. prof. Andrzej Napiórkowski, który między innymi wskazał: „Kiedy wgłębiamy się w życie i dorobek zarówno teologiczny, jak i kościelny kard. Ludwika Gerharda Müllera, przychodzi na myśl określenie św. Jana Pawła II odnośnie do jednego z krakowskich uczonych: «zawodowa kompetencja i chrześcijańska mądrość». Tak mówił Karol Wojtyła o Janie Kantym, pozostając pod wielkim urokiem tego patrona krakowskich profesorów i studentów. Uwzględniając oryginalne osiągnięcia na polu teologii, a także posługi biskupiej Kościołowi ratyzbońskiemu oraz służby jako prefekta Kongregacji Nauki Wiary całemu Kościołowi powszechnemu i współkształtowanie przez niego dobrych relacji między narodem polskim a niemieckim, mamy podstawy, aby posłużyć się tym określeniem także w stosunku do naszego znakomitego gościa, któremu nasza uczelnia nadaje dziś najwyższą akademicką godność doktora honoris causa" ${ }^{26}$.

Następnie prorektor ks. prof. dr hab. Józef Stala odczytał w języku łacińskim dyplom doktora honoris causa, po czym rektor ks. prof. dr hab. Wojciech Zyzak wypowiedział właściwą formułę i uroczyście wręczył kard. Gerhardowi Ludwigowi Müllerowi dyplom doktora honoris causa UPJPII w Krakowie.

${ }_{25}$ Por. Uchwała Nr 43/2017 Senatu Uniwersytetu Papieskiego Jana Pawła II $w$ Krakowie $z$ dnia 15 maja 2017 roku w sprawie nadania tytułu doktora honoris causa Uniwersytetu Papieskiego Jana Pawła II w Krakowie Jego Eminencji ks. Kardynałowi Gerhardowi Ludwigowi Müllerowi - Prefektowi Kongregacji Nauki Wiary, w: Promotio Doctoris Honoris Causa Pontificiae Universitatis Cracoviensis Ioannis Pauli II Eminentissimus Professor Cardinalis Gerhard Ludwig Müller, red. M. Mastyło, Kraków 2017, s. 10-11.

${ }^{26}$ A. Napiórkowski, Zawodowa kompetencja i chrześcijańska mądrość. Laudacja z okazji nadania tytułu doktora honoris causa przez Uniwersytet Papieski Jana Pawła II w Krakowie kardynałowi Gerhardowi Ludwigowi Müllerowi, prefektowi Kongregacji Nauki Wiary, w: Promotio Doctoris Honoris Causa Pontificiae Universitatis Cracoviensis Ioannis Pauli II Eminentissimus Professor Cardinalis Gerhard Ludwig Müller, red. M. Mastyło, Kraków 2017, s. 57-58. 
Kolejnym punktem uroczystości była mowa doktorska Kardynała (w języku polskim odczytał ją sekretarz Kardynała, ks. dr Sławomir Śledziewski). Jednak najpierw Kardynał skierował kilka zdań w języku polskim: „Dziękuję z całego serca za ten honor całemu Uniwersytetowi. Papieża Jana Pawła Wielkiego poznałem osobiście podczas prac Międzynarodowej Komisji Teologicznej. W roku 2002 mianował mnie biskupem Regensburga. Moją relację do Jana Pawła II opisuję także w najnowszej książce Papież. Posłannictwo i misja prezentowanej dziś właśnie w języku polskim" ${ }^{27}$. Natomiast w mowie doktorskiej odpowiedział na pytanie: Jak należy rozumieć reformę w Kościele? Najpierw wyjaśnił, co dziś właściwie znaczą słowa „reformacja” i „reforma”, a następnie wykazał, iż odnowa dokonuje się przez „nowość Chrystusa”. Powiedział między innymi: „Katolickie rozumienie ekumenizmu i reformy Kościoła ani nie pragnie przywrócenia status quo ante 1520, ani nie może akceptować zdeterminowanego przez uwarunkowania natury duchowo-historycznej paradygmatu procesu pluralizacji, który przywłaszcza sobie status quo instytucjonalnie i konfesyjnie różnych wspólnot kościelnych, ponieważ [w tego rodzaju pragnieniu i akceptacji] skrywa się diametralna sprzeczność względem woli Chrystusa. To właśnie w niej nieustannie gruntuje jedność, świętość, katolickość i apostolskość Kościoła, którego Głową jest Chrystus. Celem [ekumenizmu i reformy Kościoła] nie jest pojednana różnorodność - z położeniem akcentu na dalsze trwanie owej różnorodności, lecz [celem jest] pojednanie przeciwieństw w pewnej pogłębionej Communio in Christus: Unus et totus Christus, caput et membra... 500 lat reformacji i rozłam w Kościele - to żaden powód do protestanckiego triumfalizmu i do odnawiania katolickiego poczucia niższości. Do końca 2017 roku wszyscy powinniśmy się stać bardziej ewangeliccy i bardziej katoliccy w znaczeniu wspólnej pokuty, pojednania i odnowienia w Chrystusie. To jest właśnie reforma Kościoła [dokonująca się] nie przez nas, lecz w nas"28.

Doniosłą uroczystość zamknął rektor ks. prof. Wojciech Zyzak, zwracając się do honorowego doktora Uniwersytetu Papieskiego Jana Pawła II: „Eure Eminenz Herr Kardinal, ich möchte mich im Namen unserer ganzen Universität noch einmal für Ihre bisherige seelsorgliche Tätigkeit herzlich bedanken. Ihr Beitrag in die Geschichte der Entwicklung der Theologie - besonders in die

${ }^{27}$ Archiwum Rektoratu Uniwersytetu Papieskiego Jana Pawła II w Krakowie.

${ }^{28}$ G. L. Müller, Lectio magistralis: Jak należy rozumieć reformę $w$ Kościele?, w: Promotio Doctoris Honoris Causa Pontificiae Universitatis Cracoviensis Ioannis Pauli II Eminentissimus Professor Cardinalis Gerhard Ludwig Müller, red. M. Mastyło, Kraków 2017, s. 85-86.87. 
Entwicklung der Dogmatik und des interreligiösen Dialogs ist bewundernswert. Mit Dankbarkeit denken wir auch an die Freundlichkeit, die unsere Universität während des langjährigen Dienstes Eurer Eminenz in der Kongregation für die Glaubenslehre erfahren hat und an das Engagement im Bereich der Zusammenarbeit zwischen unseren beiden Ländern - Deutschland und Polen. Wir wünschen Euer Eminenz viel Gesundheit und Gottes Segen! Ad multos annos, Ehrwürdiger Preisträger!”29

\section{Profesor Rémi Brague - 11 stycznia 2018}

30 października 2017 roku Senat UPJPII w Krakowie na wniosek Wydziału Teologicznego podjął uchwałę w sprawie nadania prof. dr. Rémiemu Brague’owi godności doktora honoris causa UPJPII. Rémi Brague, 28. doktor honoris causa UPJPII w Krakowie, to emerytowany profesor filozofii średniowiecznej i arabskiej na Université de Paris. Wykłada również na Ludwig-MaximiliansUniversität München, gdzie piastuje stanowisko zajmowane wcześniej przez słynnego Romana Guardiniego.

Zgodnie z obowiązującymi procedurami przedmiotowa uchwała została poprzedzona uzyskaniem nihil obstat Kongregacji Edukacji Katolickiej oraz dwoma pozytywnymi recenzjami: ks. prof. dr. hab. Piotra Jaskóły (Uniwersytet Opolski) i ks. prof. dr. hab. Łukasza Kamykowskiego (Uniwersytet Papieski Jana Pawła II w Krakowie). Na laudatora został wyznaczony ks. prof. dr hab. Paweł Bortkiewicz (Uniwersytet im. Adama Mickiewicza w Poznaniu).

Ksiądz prof. Piotr Jaskóła napisał w recenzji między innymi: „Decyzja Senatu Uniwersytetu Papieskiego Jana Pawła II w Krakowie o wszczęciu, na wniosek Rady Wydziału Teologicznego, postępowania w sprawie nadania najwyższej godności akademickiej doktora honoris causa prof. Rémiemu Brague’owi jest - moim zdaniem - ze wszech miar słuszna i uzasadniona. Jednoznacznie przemawiają za tym bogactwo i oryginalność jego dorobku naukowego, aktualność podejmowanej problematyki, ustawiczne uwzględnianie perspektywy chrześcijańskiej i katolickiej, praca dydaktyczna na wielu światowych uniwersytetach, a także obiektywizm połączony z odwagą w ocenie zjawisk kulturowo, religijnie, społecznie oraz politycznie drażliwych" ${ }^{30}$. Natomiast drugi recenzent,

${ }^{29}$ Archiwum Rektoratu Uniwersytetu Papieskiego Jana Pawła II w Krakowie.

${ }^{30}$ P. Jaskóła, Opinia w postępowaniu o nadanie prof. Rémiemu Brague’owi tytułu doktora honoris causa Uniwersytetu Papieskiego Jana Pawła II w Krakowie, w: Promotio Doctoris Honoris 
ks. prof. Łukasz Kamykowski, wskazał między innymi: „uważam, że uhonorowanie przez Uniwersytet Papieski Jana Pawła II w Krakowie Rémiego Brague’a doktoratem honoris causa jest w pełni uzasadnione jego zasługami dla zrozumienia dziedzictwa kultury, apologii chrześcijaństwa katolickiego oraz dla wyciągania $\mathrm{z}$ tej mądrości moralnych wniosków, kształcenia w duchu poszanowania niezbywalnej godności osoby ludzkiej i wolności dla kształtowania szczerego dialogu między narodami, kulturami i religiami”" ${ }^{\prime 1}$.

Najwyższe akademickie wyróżnienie, godność doktora honoris causa, zostało przyznane prof. Brague’owi w szczególności za: niezłomną obronę integralnie rozumianego człowieczeństwa osoby ludzkiej; odważne przekraczanie sztucznej opozycji między naukami historycznymi, filozofią i teologią; włączenie odniesień do teologii jako inspiracji do diagnoz historycznych oraz propozycji filozoficznych; twórczy wkład w dialog chrześcijaństwa z kulturą współczesną w świecie języka francuskiego (współudział w tworzeniu francuskiej wersji „Communio”); obronę nieodzownego miejsca Boga i Kościoła w Europie; zaproponowanie interesującego punktu odniesienia do ważnych dla Polski dyskusji o jej związku z Europą rozumianą jako nośnik wartości ${ }^{32}$.

Uroczystość nadania Profesorowi doktoratu honoris causa UPJPII w Krakowie została połączona z promocjami akademickimi i odbyła się 11 stycznia 2018 roku w kolegiacie św. Anny w Krakowie. Uroczystości rozpoczęły się modlitwą brewiarzową, po której nastąpiło uroczyste wręczenie dyplomów doktorskich, doktora habilitowanego i dyplomów profesorskich. Następnie rektor UPJPII, ks. prof. dr hab. Wojciech Zyzak otworzył nadzwyczajne posiedzenie senatu, przywitał przybyłych gości oraz odczytał tekst uchwały nr 84/2017 Senatu UPJPII w Krakowie z dnia 30 października 2017 roku. Najważniejsze motywy nadania godności doktora honoris causa prof. Remiemu Brague’owi rozwinął

Causa Pontificiae Universitatis Cracoviensis Ioannis Pauli II Reverendissimus Professor Rémi Brague, red. M. Mastyło, Kraków 2018, s. 26.

${ }_{31}$ Ł. Kamykowski, Recenzja dorobku prof. dr. Rémiego Brague’a w związku z przewodem o nadanie godności doktora honoris causa przez Wydział Teologiczny Uniwersytetu Papieskiego Jana Pawła II w Krakowie, w: Promotio Doctoris Honoris Causa Pontificiae Universitatis Cracoviensis Ioannis Pauli II Reverendissimus Professor Rémi Brague, red. M. Mastyło, Kraków 2018, s. 42.

${ }^{32}$ Por. Uchwała Nr 84/2017 Senatu Uniwersytetu Papieskiego Jana Pawła II w Krakowie $z$ dnia 30 października 2017 r. w sprawie nadania tytułu doktora honoris causa Uniwersytetu Papieskiego Jana Pawła II w Krakowie Panu Profesorowi Rémiemu Brague’owi, w: Promotio Doctoris Honoris Causa Pontificiae Universitatis Cracoviensis Ioannis Pauli II Reverendissimus Professor Rémi Brague, red. M. Mastyło, Kraków 2018, s. 10. 
w swej laudacji ks. prof. Paweł Bortkiewicz, który między innymi wskazał: „jest pan jednym z sygnatariuszy Deklaracji Paryskiej Europa, w jaka wierzymy. Wraz z innymi napisał pan w jej końcowym fragmencie: «Naszą przyszłością jest prawdziwa Europa. Zapraszamy zatem wszystkich Europejczyków, by dołączyli do nas i odrzucili utopijną fantazję multikulturowego świata bez granic. Kochamy nasze ojczyzny i pragniemy przekazać naszym dzieciom każdą szlachetną rzecz, którą sami kiedyś - jako spuściznę - otrzymaliśmy. Jesteśmy Europejczykami i dzielimy wspólne dziedzictwo. To dziedzictwo domaga się, byśmy żyli razem w pokoju jako Europa narodów. Odnówmy naszą narodową suwerenność i odzyskajmy godność, która płynie ze wspólnej odpowiedzialności za przyszłość Europy»»33. Pragniemy zapewnić pana, że jest pan we wspólnocie ludzi, którzy podzielają pańską odpowiedzialność za przyszłość naszego kontynentu i naszej cywilizacji. Jest zaszczytem dla naszego środowiska naukowego, kulturalnego i religijnego w Polsce, że możemy cieszyć się pańską obecnością w naszym kraju, który od 1050 przeszło lat jako kraj chrześcijański należy do Europy. Zaszczyt pańskiej obecności naznaczonej mądrością i autorytetem płynącym z wiedzy spływa przede wszystkim na Kraków i jego środowisko naukowe, a zwłaszcza na Uniwersytet Papieski Jana Pawła II"34.

Po laudacji prorektor ks. prof. dr hab. Józef Stala odczytał w języku łacińskim dyplom doktora honoris causa, zaś ektor ks. prof. Wojciech Zyzak uroczyście wręczył prof. Rémiemu Brague’owi dyplom doktora honoris causa UPJPII w Krakowie. Po nadaniu godności życzenia wypowiedział wielki kanclerz UP JPII abp Marek Jędraszewski: „Szanowny Panie Profesorze! Z całego serca dziękujemy Panu za Pana wielkie intelektualne dzieło rozumienia Europy, a także za odważną i pełną mądrości jej obronę, co poza licznymi Pańskimi dziełami znalazło swój wyraz również w opracowanej i ogłoszonej między innymi przez Pana Deklaracji Paryskiej".

Kolejnym punktem uroczystości była mowa doktorska Profesora: Lectio magistralis. Co Europa może uczynić z chrześcijaństwem?, w której między innymi

${ }^{33}$ Europa, w jaka wierzymy. Deklaracja Paryska, czyli apel wybitnych intelektualistów wzywajacych do ratowania kontynentu, https://wpolityce.pl/spoleczenstwo/362106-europa-w-jaka-wierzymy-deklaracja-paryska-czyli-apel-wybitnych-intelektualistow-wzywajacych-do-ratowania-kontynentu-to-trzeba-przeczytac (10.11.2017).

${ }^{34}$ P. Bortkiewicz, Filozof $w$ stużbie człowieka i cywilizacji. Laudacja $z$ okazji nadania prof. dr. Rémiemu Braguéowi doktoratu honoris causa Uniwersytetu Papieskiego Jana Pawła II w Krakowie, w: Promotio Doctoris Honoris Causa Pontificiae Universitatis Cracoviensis Ioannis Pauli II Reverendissimus Professor Rémi Brague, red. M. Mastyło, Kraków 2018, s. 61-62. 
podkreślił: „Boże spojrzenie na to, co ludzkie jest szersze niż samych ludzi. Boża antropologia jest bardziej pomysłowa niż ludzka. Bóg patrzy na człowieka w sposób bardziej pozytywny i bardziej optymistyczny, niż człowiek patrzy na samego siebie. W konsekwencji Bóg ma więcej ambicji dla człowieka, niż ma jej człowiek dla siebie samego. Europa będzie istniała tak długo, jak długo jej ambicja, jej poczucie własnej godności będzie się zapalać od światła Bożej ambicji”" ${ }^{35}$.

Opisani doktorzy honoris causa Uniwersytetu Papieskiego Jana Pawła II w Krakowie dołączyli do szlachetnego grona, do którego należą m.in.: prof. Lorenzo Ornaghi (10 x 2013), ks. dr Hieronim Fokciński sı i ks. prof. Stanisław Czerwik (11 VI 2013), ks. prof. Wendelin Knoch (7 XI 2012), kard. prof. Tarcisio Bertone SD B ( 8 VI 2012) oraz 17 osób, które otrzymały tę godność w Papieskiej Akademii Teologicznej w Krakowie: bp prof. Julian Wojtkowski (3 III 2009), prof. Carl A. Anderson (20 x 2007), kard. prof. Marian Jaworski (8 VI 2006), prof. Franciszek Ziejka (3 Vi 2005), Hanna Suchocka (28 I 2005), kard. Audrys Juozas Backis (13 V 2003), kard. Miloslav Vlk (7 V 2001), kard. Franciszek Macharski (14 IV 200o), prof. Hermann Josef Pottmeyer (23 VI 1998), prof. Vincent Coyne SI (21 X 1997), prof. Augustyn Jankowski OsB (8 XII 1996), ks. prof. Bolesław Kumor (19 XI 1994), prof. Burkhard Neunheuser OsB (21 X 1992), kard. Andrzej Maria Deskur (15 XI 1991), prof. Paulius Rabikauskas SI (19 X 1991), prof. Radim Palous (19 X 1991), kard. Agostino Casaroli (2 VI 1990).

Wszystkie osoby, które otrzymały tytuł honorowy doctor honoris causa nadany przez Uniwersytet Papieski Jana Pawła II w Krakowie w latach 2015-2018, przyczyniły się w znaczący sposób do zrozumienia dziedzictwa kultury europejskiej i wydobycia moralnych wniosków służących jej rozwojowi w duchu poszanowania niezbywalnej godności osoby ludzkiej oraz dialogu między narodami, kulturami i religiami. Każda z tych osób wniosła swój oryginalny wkład $\mathrm{w}$ tworzenie kultury i budowanie fundamentów antropologicznych od poszukiwania wartości człowieka w strasznych czasach konfliktów zbrojnych, przez dawanie swoim życiem, posługą, nauczaniem świadectwa Prawdzie, przez obronę najważniejszych wartości i wyznaczanie nowych kierunków badawczych,

${ }^{35}$ R. Brague, Lectio magistralis. Co Europa może uczynić z chrześcijaństwem?, w: Promotio Doctoris Honoris Causa Pontificiae Universitatis Cracoviensis Ioannis Pauli II Reverendissimus Professor Rémi Brague, red. M. Mastyło, Kraków 2018, s. 65.83-84. 
aż po odbudowywanie odpowiedzialności za przyszłość Europy. W kontekście obecnej kultury, bardzo często deprecjonującej wartość i godność człowieka, szczególną wartość posiada postawa wszystkich zaprezentowanych honorowych doktorów Uniwersytetu Papieskiego Jana Pawła II w Krakowie. Można ich uznać za obrońców „cywilizacji miłości” rozwijających myśl Jana Pawła II, że jedynie miłość może zagwarantować ochronę osobowej godności człowieka, bowiem tylko miłość jako w pełni bezinteresowna więź, pragnie dobra i tworzy dobro.

\section{Bibliografia}

Europa, w jaka wierzymy. Deklaracja Paryska, czyli apel wybitnych intelektualistów wzywajacych do ratowania kontynentu, https://wpolityce.pl/spoleczenstwo/362106-europa-w-jaka-wierzymy-deklaracja-paryska-czyli-apel-wybitnych-intelektualistow-wzywajacych-do-ratowania-kontynentu-to-trzeba-przeczytac (10.11.2017). Promotio Doctoris Causa Pontificiae Uniwersitatis Cracoviensis Ioannis Pauli II Reverendissimus Profesor Michael Heller, red. M. Wiertek, Kraków 2016.

Promotio Doctoris Honoris Causa Pontificiae Universitatis Cracoviensis Ioannis Pauli II Eminentissimus Professor Cardinalis Gerhard Ludwig Müller, red. M. Mastyło, Kraków 2017.

Promotio Doctoris Honoris Causa Pontificiae Universitatis Cracoviensis Ioannis Pauli II Reverendissimus Professor Rémi Brague, red. M. Mastyło, Kraków 2018. Promotio Doctoris Honoris Causa Pontificiae Universitatis Cracoviensis Ioannis Pauli II Reverendissimus Profesor Elie Wiesel, red. M. Wiertek, Kraków 2015. Promotio Doctoris Honoris Causa Pontificiae Universitatis Cracoviensis Ioannis Pauli II Sua Sanctitas Benedictus XVI, red. M. Wiertek, Kraków 2015.

Promotio Doctoris Honoris Causa Pontificiae Universitatis Cracoviensis Ioannis Pauli II Reverendissima Excellentia Caelestinus Migliore, red. M. Wiertek, Kraków 2015.

\section{Streszczenie}

Doktor honoris causa jest stopniem akademickim przyznawanym komuś, kto miał szczególny wkład w rozwój określonej dyscypliny, społeczeństwa lub Kościoła. W latach 2015-2018 doktorat honoris causa Uniwersytetu Papieskiego Jana Pawła II w Krakowie otrzymali: Profesor Elie Wiesel - 30 czerwca 2015, 
Papież Benedykt XVI - 3 lipca 2015, Arcybiskup Celestino Migliore - 16 października 2015, Ksiądz Professor Michał Heller - 22 czerwca 2016, Kardynał Profesor Gerhard Ludwig Müller - 16 października 2017, Profesor Rémi Brague 11 stycznia 2018. W niniejszym artykule są przedstawione wszystkie osoby docenione przez Uniwersytet Papieski Jana Pawła II w Krakowie za wysiłki na rzecz pokojowego rozwiązywania konfliktów na całym świecie poprzez promowanie międzywyznaniowego dialogu, zrozumienie, wnikliwą inteligencję oraz ich znaczący wkład na rzecz Kościoła.

\section{Słowa kluczowe}

Uniwersytet Papieski Jana Pawła II Krakowie, doktorzy honoris causa, nauka, kultura

\section{Summary}

Particularly Meritorious for Science and Culture. Doctors Honoris Causa of The Pontifical University of John Paul II in Krakow in the years 2015 to 2018

Doctor Honoris Causa is an academic degree awarded to someone who has contributed in a special way to a specific field or to society, or Church in general. In the years 2015 to 2018 The Pontifical University of John Paul II has conferred the degree of Doctor Honoris Causa on Professor Elie Wiesel - 30 June 2015, The Pope Benedict XVI - 3 July 2015, Archbishop Celestino Migliore - 16 October 2015, Rev. Professor Michał Heller - 22 June 2016, Cardinal Professor Gerhard Ludwig Müller - 16 October 2017, Professor Rémi Brague - 11 January 2018. This article presents all these persons acclaimed by UPJPII their efforts to promote the peaceful resolution of conflict throughout the world by promoting interfaith dialogue, understanding, incisive intelligence and their significant contribution to the Church.

\section{Keywords}

The Pontifical University of John Paul II in Krakow, Doctors Honoris Causa, science, culture 